\title{
Analogue GPR study of the Permian fanglomerates from Zygmuntówka Quarry near Chęciny, Holy Cross Mountains, southern Poland, for construction of a training image for multiple point simulations
}

\author{
Tomasz ŻUK ${ }^{1, *}$, Zbigniew MAŁOLEPSZY ${ }^{1}$ and Ewa SZYNKARUK ${ }^{1}$ \\ 1 Polish Geological Institute - National Research Institute, Rakowiecka 4, 00-975 Warszawa, Poland
}

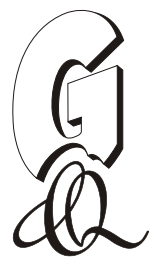

Żuk, T., Małolepszy, Z., Szynkaruk, E., 2018. Analogue GPR study of the Permian fanglomerates for construction of a training image for multiple point simulations, Zygmuntówka Quarry, Holy Cross Mountains, southern Poland. Geological Quarterly, 62 (4): 755-766, doi: 10.7306/gq.1438

Associate editor: Anna Wysocka

The distribution of Permian alluvial fan lithofacies in a quarry at Zygmuntówka near Chęciny, Holy Cross Mts., in southern Poland was investigated using ground penetrating radar (GPR) in order to create a training image for multiple point statistics (MPS) reconstructions of alluvial fan sedimentary facies. Five pseudo-3D GPR datasets were collected, processed and uploaded for interpretation into SKUA-GOCAD 3D geological modelling software. Three radar facies were distinguished based on the 3D geometrical pattern of radar reflections and linked to lithofacies described from the quarry by Zbroja et al. (1998). A statistical summary showed that $\sim 50 \%$ of the lithofacies resulted from gravity flows (mostly non-cohesive), while the remaining proportion was deposited by unconfined and confined flash floods. Fluvial sedimentary facies left by waning of catastrophic floods or reworking during fair weather, although not prevalent, could not be distinguished from confined flood deposits based only on GPR data. The GPR datasets together with information from field observations were used to carry out MPS simulations and estimate the most probable 3D model of lithofacies at the quarry scale. This model will in turn serve as a training image for MPS reconstructions of alluvial-fan facies of Rotliegend conglomerates in the multi-scale geological model of the Gorzów Block (western Poland).

Key words: alluvial fans, ground penetrating radar, Permian conglomerates, sedimentary facies, multiple point statistics, training image.

\section{INTRODUCTION}

Multi-scale 3D geological modelling of the sedimentary cover of the Gorzów Block (western Poland; Fig. 1), apart from delineating the stratigraphic systems and main tectonic structures, also involves reconstructing the spatial distribution of sedimentary facies for the most important horizons overlying the Variscan basement. In the Gorzów Block, as in other post-Variscan intra-continental basins of Western and Central Europe, the tectonically deformed basement of Precambrian to Carboniferous age is discordantly covered by the Permian and younger systems. However, the great depth of these strata and sparse borehole data motivate us to use analogues of the dominant lithostratigraphic units to properly delineate facies distribution. A significant proportion of the Permian sedimentary cover on the Gorzów Block is formed of alluvial-fan conglomerates which accumulated around volcanic elevations on the north-

\footnotetext{
* Corresponding author, e-mail: tomasz.zuk@pgi.gov.pl
}

Received: March 14, 2016; accepted: May 15, 2018; first published online: November 23, 2018 western part of the Wolsztyn High (Fig. 1). These facies - accessible only in deep boreholes in the Gorzów Block - were described by Pokorski (1988) as alluvial fan conglomerates of the basal part of the Noteć Formation. Karnkowski (1994) described them as an allostratigraphic unit of the Książ Wielkopolski Conglomerate, while Kiersnowski and Buniak (2006) as conglomerates of the ALIII depositional cycle. The nearest outcrops of comparable Permian facies can be found in the Sudetes, near Kraków and near Chęciny in the Holy Cross Mts. (Fig. 1). Quantitative relationships measured in analogue geological situations compared with facies models established based on observations from contemporary alluvial fans (for example Nemec and Steel, 1984; Blair and McPherson, 1992, $1994 a, b)$ can aid reconstructions of sedimentary facies distribution in inaccessible situations, i.e. between deep boreholes. One approach to reconstructing this facies involves using multiple point statistics (MPS), which requires training images.

Training images are conceptual models representing the spatial arrangement of properties. They are constructed based on observations from exposures, high-resolution geophysical data such as ground penetrating radar (GPR), understanding of facies models and sedimentary processes, 3D geometrical modelling techniques or other quantitative methods (Comunian et al., 2011; Linde et al., 2015). Training images offer an alter- 


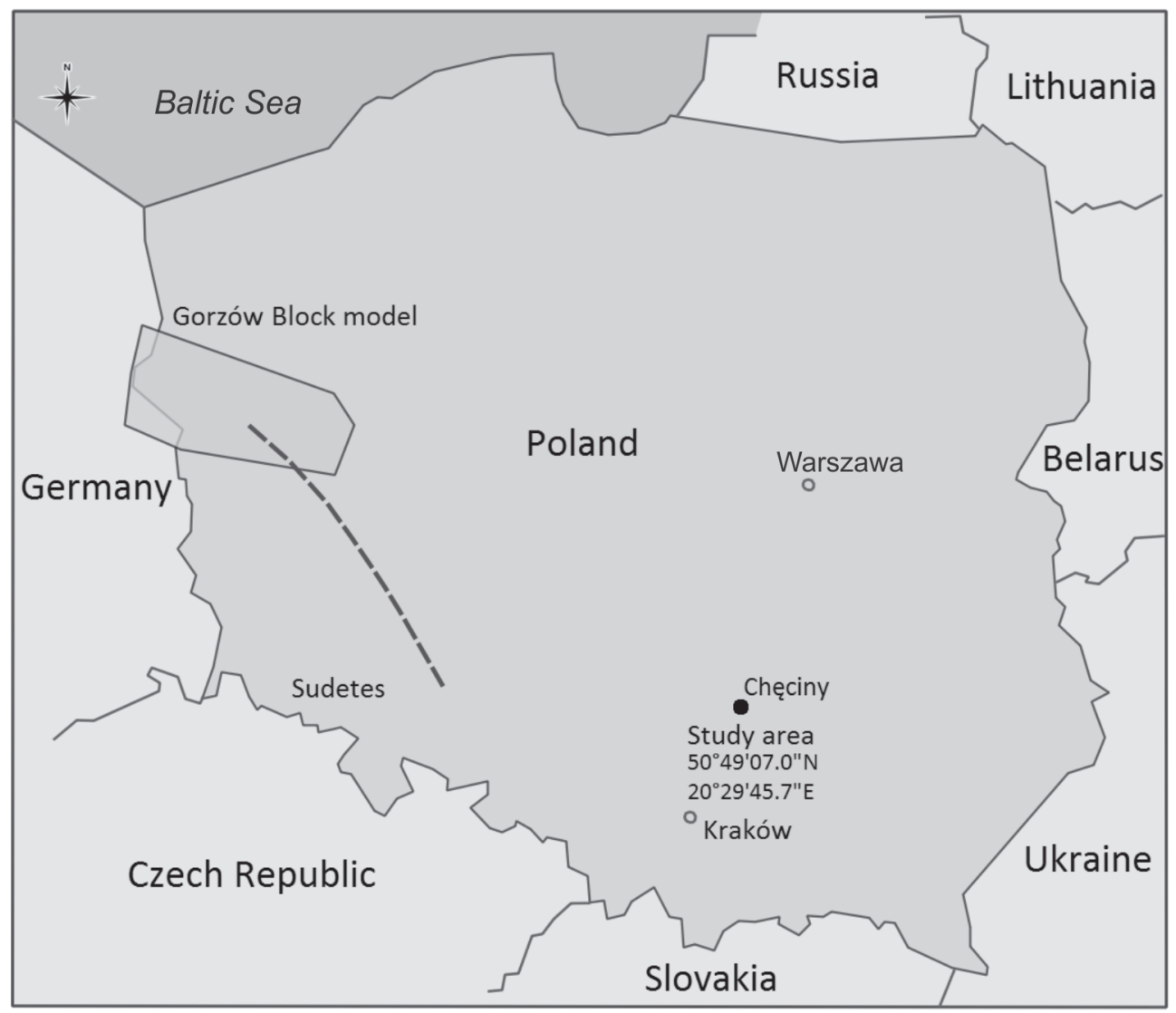

Fig. 1. Location of the study site near Chęciny in southern Poland and the extent of the Gorzów Block model

Black dashed line indicates location of the Wolsztyn High

native to variogram-based geostatistics, which deals with spatial relationships between two measurement points, but cannot resolve complex patterns such as the arrangement of sedimentary facies (Guardiano and Srivastava, 1992; Strebelle, 2002). During simulations, the MPS algorithm scans the training image, extracts relationships between multiple data points and applies them to available subsurface data from a new site in order to stochastically recreate multiple, equally possible, new distributions.

Numerous studies of alluvial fanglomerates show a great similarity of alluvial fan architecture, particularly their main sedimentary facies (cf. Nemec and Steel, 1984; Nemec and Postma, 1993; Blair and McPherson, 1994a, b; Maejima and Nakanishi, 1994; Blair, 2000; Kim and Lowe, 2004). This is due to the dominant role of gravity flow processes as well as catastrophic floods both in desert and non-desert environments. Typical alluvial fan facies are primarily formed by sub-aerial gravity flows and catastrophic (flash) floods (supercritical flow of Newtonian fluid) as described by Nemec and Steel (1984) and Blair and McPherson (1994b). Fluvial processes associated with subcritical flow occur on alluvial fans only during the waning phase of catastrophic flows (forming the top part of the sequence) or in fair-weather conditions when they only modify the alluvial fan surface. Most surface observations from alluvial fans were carried out during dry weather which led to the common association of alluvial fan environments with fluvial processes (Blair and McPherson, 1994a).

Bedrock lithology and climate are two primary controlling factors for weathering processes, which after deposition of sed- imentary material may result in differences in matrix amount and type (Thiry et al., 1999; Taylor and Eggleton, 2001). However, a greater amount of fine particles will only favour cohesive debris flows over non-cohesive flows during the initial stage of bedrock erosion and fan development (type I alluvial fans of Blair and McPherson 1994a). During MPS simulations, proportions of sedimentary facies can be imposed based on hard data such as borehole information. Thus for the purpose of creating a training image, it is possible to compare alluvial fans built by sedimentary material of different compositions, such as fans comprising carbonate clasts as is the case at Zygmuntówka Quarry, with those composed of fragments of volcanic or clastic sedimentary rocks (Gorzów Block).

The aim of this article is to demonstrate the process of developing a training image based on pseudo-3D ground penetrating radar (GPR) data collected from outcrops and correlated with exposure observations. We discuss the applicability of such an approach using data collected from the Zygmuntówka Quarry near Chęciny in southern Poland. The phase of applying the training image in reconstructing sedimentary lithofacies with MPS based on the example of the Gorzów Block is outside the scope of this article and will be described in a separate publication.

\section{GEOLOGICAL SETTING}

Coarse-grained clast-supported, occasionally matrix-supported, conglomerates of Late Permian age are exposed in the Zygmuntówka Quarry at the hill of Czerwona Góra, located near 


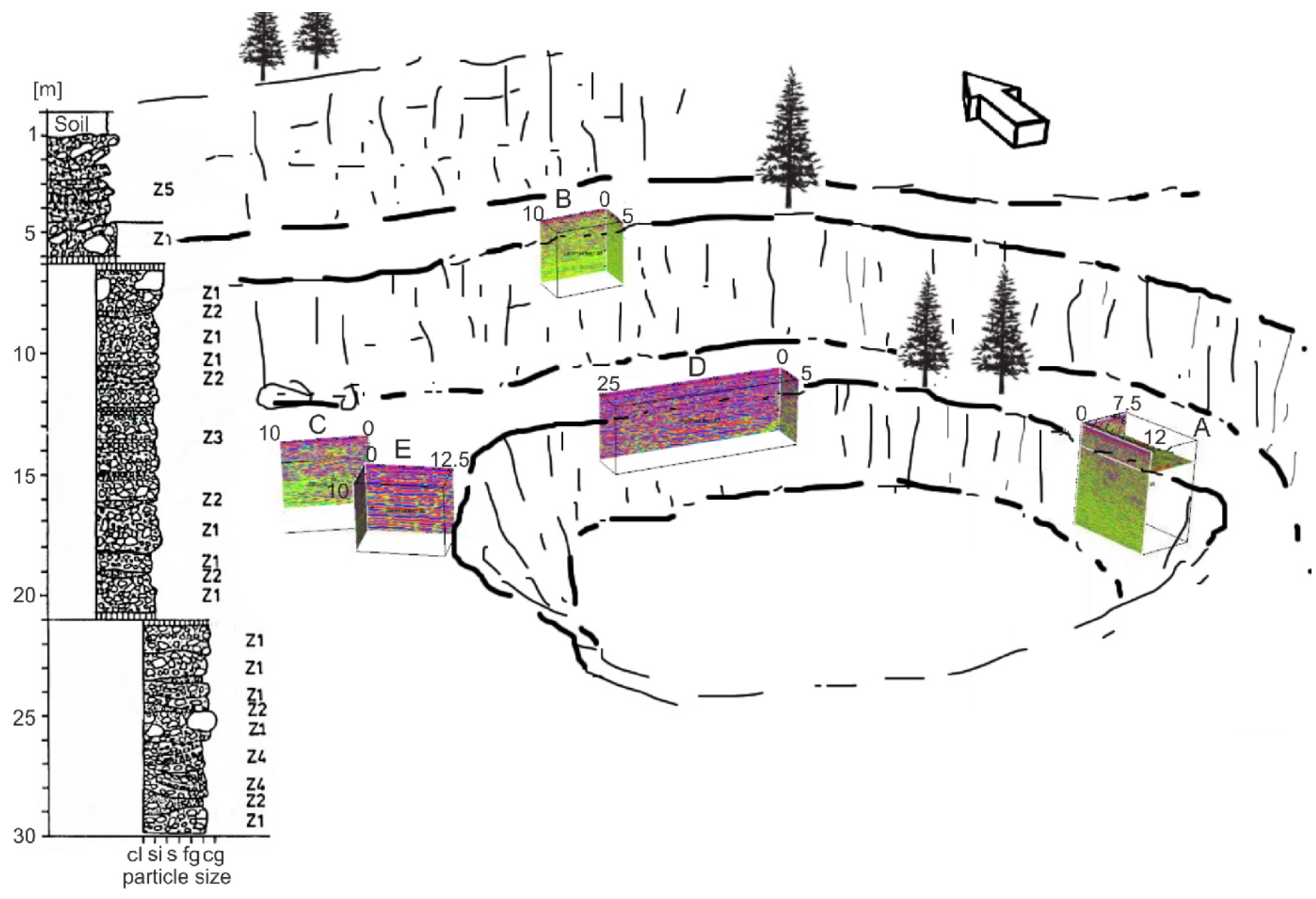

Fig. 2. Field sketch of the quarry with location of GPR datasets and the geological profile from Zbroja et al. (1998) showing distribution of the main lithofacies Z1-Z5

Z1 - thickly-bedded, structureless, clast-supported; Z2 - thickly-bedded, structureless, matrix-supported; Z3 - thinly- to medium-bedded, clast-supported, poorly sorted; Z4 - trough cross-bedded conglomerates, occasionally with normal grading; Z5 - structureless, clast-supported conglomerates arranged in both planar and trough-shaped beds; symbols showing clast size: cl - clay, si - silt, s - sand, fg - fine gravel, cg - coarse gravel; A-E - GPR datasets; numbers near GPR datasets indication their dimensions in metres; the arrow indicates the north

the town of Chęciny (Holy Cross Mts.) $\sim 10 \mathrm{~km}$ south of Kielce, southern Poland (Figs. 1 and 2). The Permian strata have not been significantly tectonically deformed here, bedding being gently inclined at an angle of $\sim 5$ to the south-west, i.e. the dominant transport direction (Kostecka, 1962). Thus the study site offers excellent conditions to study the depositional architecture of an ancient alluvial fan.

The alluvial-fan facies unconformably overlie deformed Upper Devonian and locally Lower Carboniferous carbonates forming palaeopiedmont settings for the Permian deposits of an arid and semi-arid climate. Here, the thickness of the Permian succession reaches over $150 \mathrm{~m}$ as recorded in borehole BZ1 located $\sim 1.5 \mathrm{~km}$ to the south-east of the study site (Kuleta et al., 2007). Only the uppermost $30 \mathrm{~m}$ thick section of the Upper Permian conglomerates is exposed in the quarry and is interpreted to have been deposited as a proximal to intermediate alluvial fan. General upwards coarsening of clasts suggests a prograding fan system (Zbroja et al., 1998). The lower part of the profile located to the south-east of Zygmuntówka was interpreted to consist of shallow fan-delta deposits, as suggested by the presence of limestone beds and the chemical composition of the matrix (Migaszewski et al., 1996; Kuleta et al., 2007).
Zbroja et al. (1998) described five lithofacies within the Zygmuntówka conglomerates (Fig. 2). The first two are thickly-bedded, structureless, clast-supported (lithofacies Z1) and matrix-supported (lithofacies Z2), poorly sorted conglomerates with cobbles and boulders. Lithofacies Z1 forming $\sim 40 \%$ of the rock volume was deposited by non-cohesive gravity flows (Gani, 2004), also defined as pseudoplastic grain flows (Nemec, 2009) or the liquefied flows of Middleton and Hampton (1973). Matrix-supported gravels with cobbles and boulders (Z2) are cohesive gravity flow deposits (Bingham plastic rheology, Nemec 2009) and represent only $10 \%$ of the rock volume. The third lithofacies is described as subhorizontally bedded, clast-supported, poorly sorted conglomerate (lithofacies Z3) with clast dimensions reaching $0.3 \mathrm{~m}$, commonly normally graded. Lithofacies Z3 is interpreted as deposits associated with unconfined, supercritical flow produced by catastrophic flash floods (sheetfloods). Trough cross-bedded conglomerates with occasional normal grading were classified as lithofacies Z4 ascribed to deposition from small streams. Structureless clast-supported conglomerates are arranged in both planar and trough-shaped beds and described as lithofacies Z5. They are ascribed to confined (channelized) 


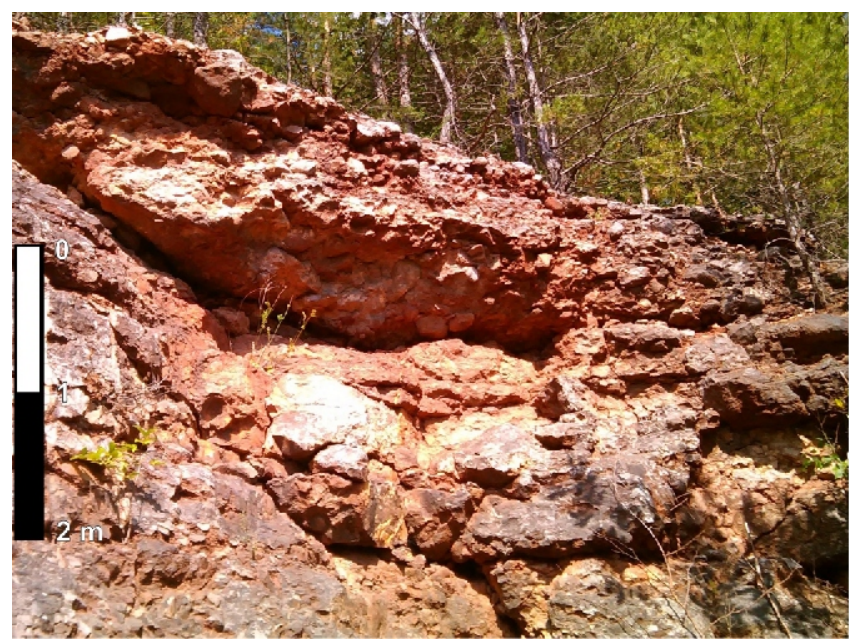

Fig. 3. Lithofacies $Z 5$ in the uppermost quarry face, photo facing the north

flashfloods (as described by Simons and Richardson, 1966) representing incised-channel fills and the embankments surrounding them (Fig. 3).

\section{METHODS}

GPR sends short electromagnetic impulses which are reflected back to the surface from interfaces between zones of contrasting dielectric properties and recorded by a receiver. We used RAMAC GPR with a $250 \mathrm{MHz}$ shielded antenna. Five pseudo-3D GPR datasets were collected with their lateral dimensions ranging from 5 to $25 \mathrm{~m}$ (Fig. 2). Signal penetration reached on average a depth of $10 \mathrm{~m}$. Each dataset comprised a series of parallel 2D GPR profiles with a distance between lines of $0.2 \mathrm{~m}$ and a survey step of $0.1 \mathrm{~m}$ forming a survey grid close to full-3D resolution (Grasmueck et al., 2005; Dogan et al., 2011). Closely spaced parallel GPR profiles were individually processed (frequency bandpass filtering, gains, in some datasets topographic correction), and $2 \mathrm{D}$ lines were compiled into 3D datasets. Large amounts of cobbles and boulders introduced hyperbola-shaped reflections which obscured the images, and only after the data was migrated (2D Stolt) profiles were interpretable. Signal velocity for the data migration, topographic correction and time-to-depth conversion was established at two locations in the quarry (at the centre of grids $A$ and D) to be $0.087 \mathrm{~m} / \mathrm{ns}$ based on the thickness of strata known from the quarry exposures. The GPR method is analogous to seismic reflection, therefore processed pseudo-3D GPR data could be uploaded for interpretation into SKUA-GOCAD geological modelling software. Field observations were also carried out in order to verify the location of sedimentary facies in the quarry cliffs, particularly in the topmost quarry face, which was not available for acquisition of GPR data due to vegetation and an uneven ground surface.

\section{RESULTS AND INTERPRETATION}

\section{CLASSIFICATION OF RADAR FACIES}

Classification of radar facies was based on concepts of radar stratigraphy (Beres and Heani, 1991; Gawthorpe et al.,
1993; Huggenberger, 1993) which were adopted from seismic stratigraphy (Mitchum et al., 1977). Radar facies were defined by Huggenberger (1993) as mappable, three-dimensional sedimentary units characterized by reflections the spatial pattern of which distinguishes it from adjacent units. The 3D approach to radar facies representations involves recognising a reflection pattern in all three directions $(x-y-z)$. Large-scale sedimentary structures (decimetre-scale) apparent on GPR profiles and interfaces between zones of contrasting electromagnetic properties were manually picked across datasets. Horizontal sections (time slices) were particularly useful because they allowed the tracing of horizons between adjacent 2D lines within 3D datasets, which otherwise would be difficult to correlate in some areas (Fig. 4). As in the case of seismic data, the main properties which describe the character of reflection surfaces are their amplitude, shape, dip, azimuth of inclination, continuity as well as spatial relationships with other interfaces, particularly of higher order (surfaces between radar facies).

Dip and azimuths of surfaces (manually traced) were automatically calculated by the modelling software, displayed on surfaces and summarized for interpretation using histograms. Generally, the steeply inclined, typically at an angle of 6 to 15 and locally reaching 20 (Figs. $4 \mathrm{~B}$ and 5 ), tabular arrangement of radar reflections was classified as radar facies $Z 1 / Z 2$. This description which merged facies $Z 1$ and $Z 2$ was made in order to link the radar facies to the classification of lithofacies of Zbroja et al. (1998) for the study site (explained in the interpretation section). Subhorizontal continuous parallel reflections inclined at an angle of between 2 and 8 were grouped as radar facies Z3. Trough-shaped concordant reflections, typically semicontinuous, were named radar facies Z4/Z5 (Fig. 5). These troughs were very irregular in shape, depth and lateral extent, but on average their depth was 1-3 $\mathrm{m}$ with lateral extents of 3-8 $\mathrm{m}$. The summary of radar facies correlated with the lithofacies of Zbroja et al. (1998) is shown in Figure 6.

The most distinct (highest amplitude) reflections were manually traced and transformed into surfaces using geomodelling software (Figs. 5 and 6). Most reflections were difficult to trace, particularly the trough-shaped ones, as they continue laterally only for 2 to $5 \mathrm{~m}$. This is consistent with descriptions of bedding continuity from contemporary alluvial fans (e.g., Blair, 2000). Thus tracing surfaces between 3D GPR datasets (cubes) was not realistic. The surfaces were classified according to the radar facies they belonged to; their inclination and azimuth was extracted using the software, and summarized as histograms and basic statistical values. Based on this summary, reflection surfaces of radar facies Z1/Z2 were the most steeply inclined at an average angle of $11^{\circ}$ with a standard deviation value of 6.3. Inclination of surfaces clearly increased with depth with maximum values of over $20^{\circ}$ in the bottom parts of the quarry. Radar facies Z3 was associated with an average dip of $7.6^{\circ}$ and standard deviation of $\sim 4$. Some surfaces in the upper sections associated with facies $\mathrm{Z} 3$ are very shallow and their angle of inclination was $<3^{\circ}$.

The average azimuth values for each of the radar facies are quite similar, although in the case of lithofacies Z3 the mean azimuth of inclination was $232.8^{\circ}$, the most similar to the azimuth of inclination of the Devonian subcrop $\left(234^{\circ}\right)$. This subcrop surface was traced based on the Detailed Geological Map of Poland at the scale of 1:50,000, Chęciny Sheet (Hakenberg, 1971). For this facies, the standard deviation is the highest $\left(\sim 53^{\circ}\right)$ and the distribution is clearly bimodal which may reflect the convex shape of the alluvial fan topography. The azimuth for radar facies $Z 1 / Z 2$ is the most westerly $\left(245^{\circ}\right)$, while the standard deviation is the lowest $\left(26^{\circ}\right)$. 


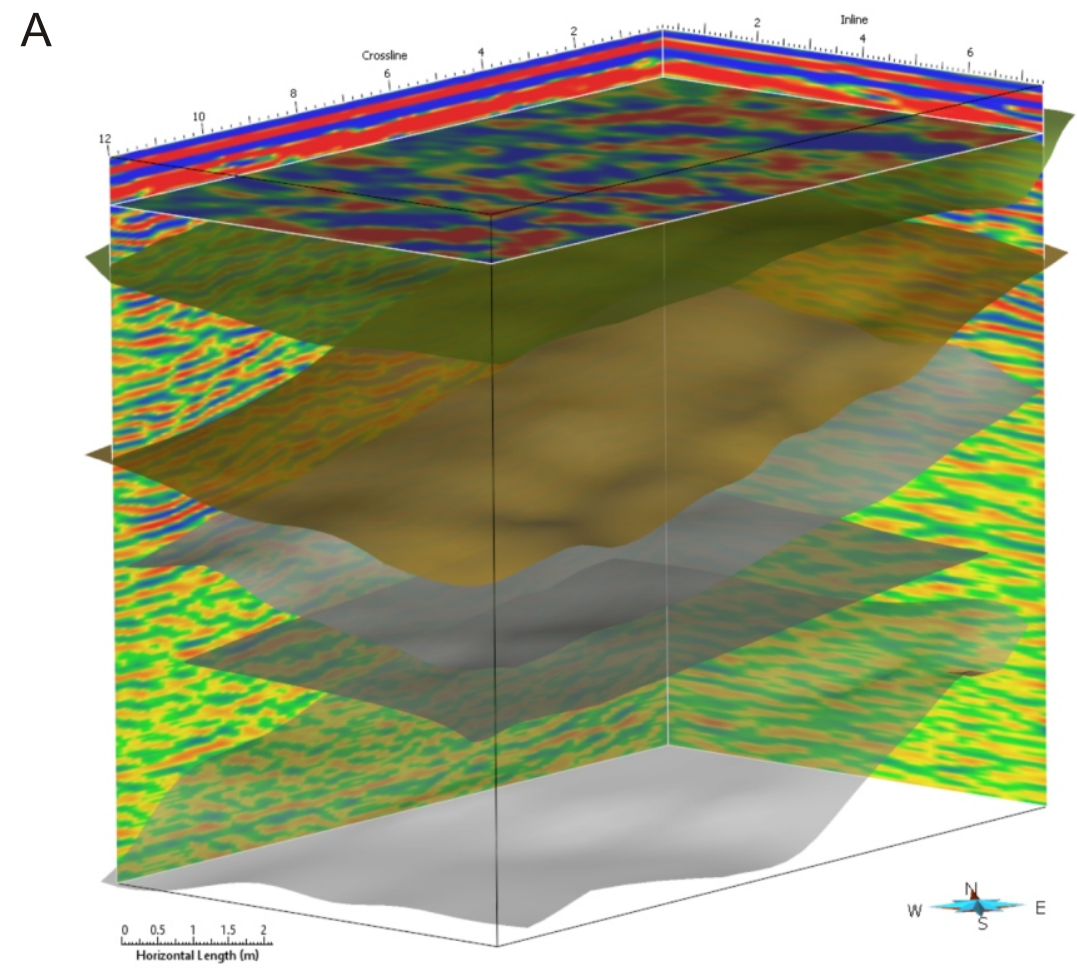

B

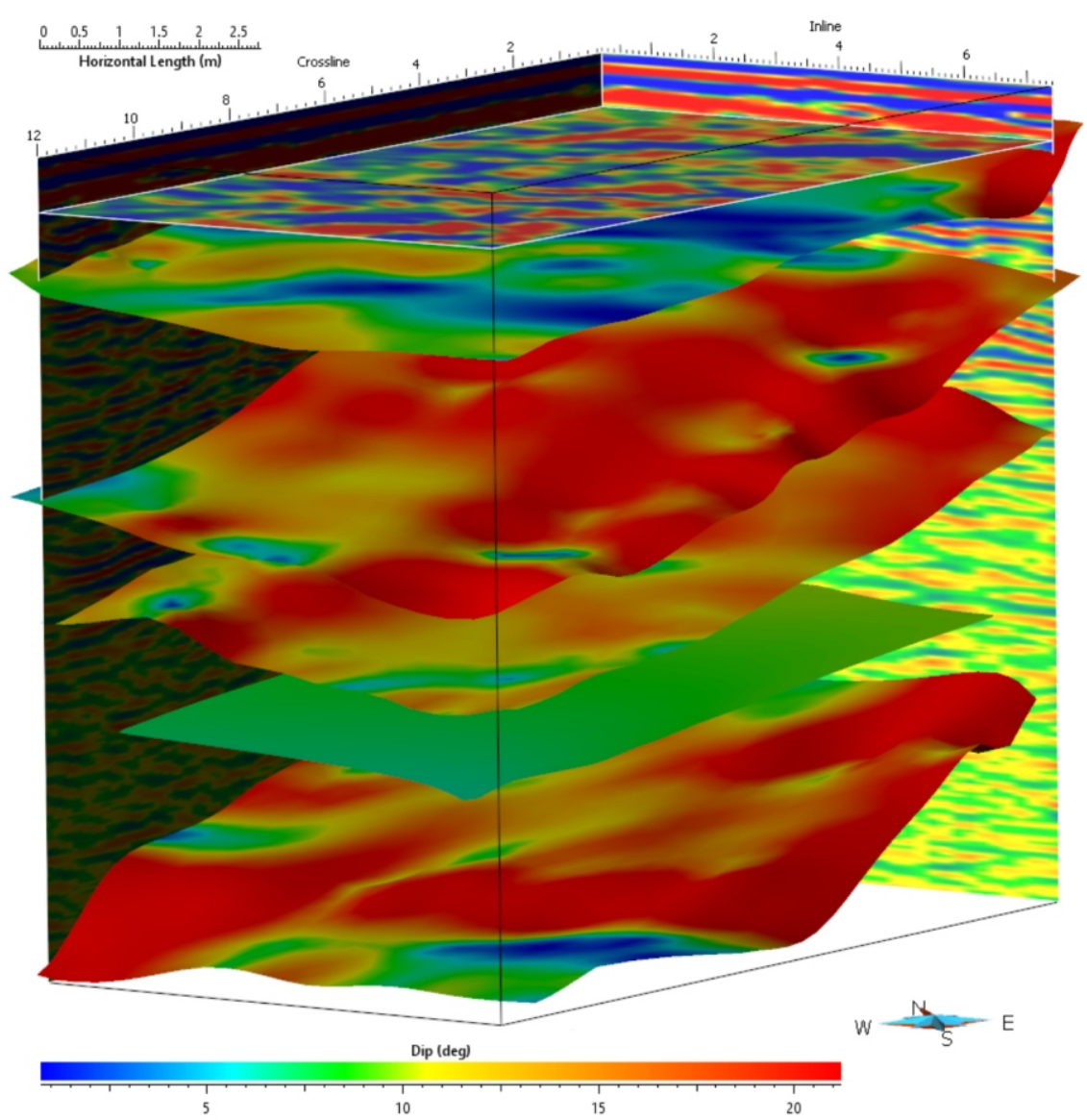

Fig. 4. GPR dataset $A$

A - with dimensions $12 \times 7 \mathrm{~m}$ located in the eastern part of the lowest bench of the quarry; note the azimuth of inclination also can be inferred from the horizontal section (at the top of the dataset); these horizontal sections helped to trace the horizons between parallel 2D GPR profiles forming each of the pseudo-3D datasets; total vertical reach in two-way-travel time (TWTT) is $220 \mathrm{~ns}(100 \mathrm{~ns}=4.35 \mathrm{~m})$; B - with some of the horizons displayed and showing dip inclination (in degrees); note the very high angles of inclination on the second, third and bottom horizons (locally reaching 20 ); the second horizon from the bottom with values below 10 is associated with radar facies Z3; the undulations on the surfaces may have resulted from data acquisition, processing and interpretation, i.e. manual picking of surfaces; total vertical reach in TWTT is $220 \mathrm{~ns}(100 \mathrm{~ns}=4.35 \mathrm{~m})$ 


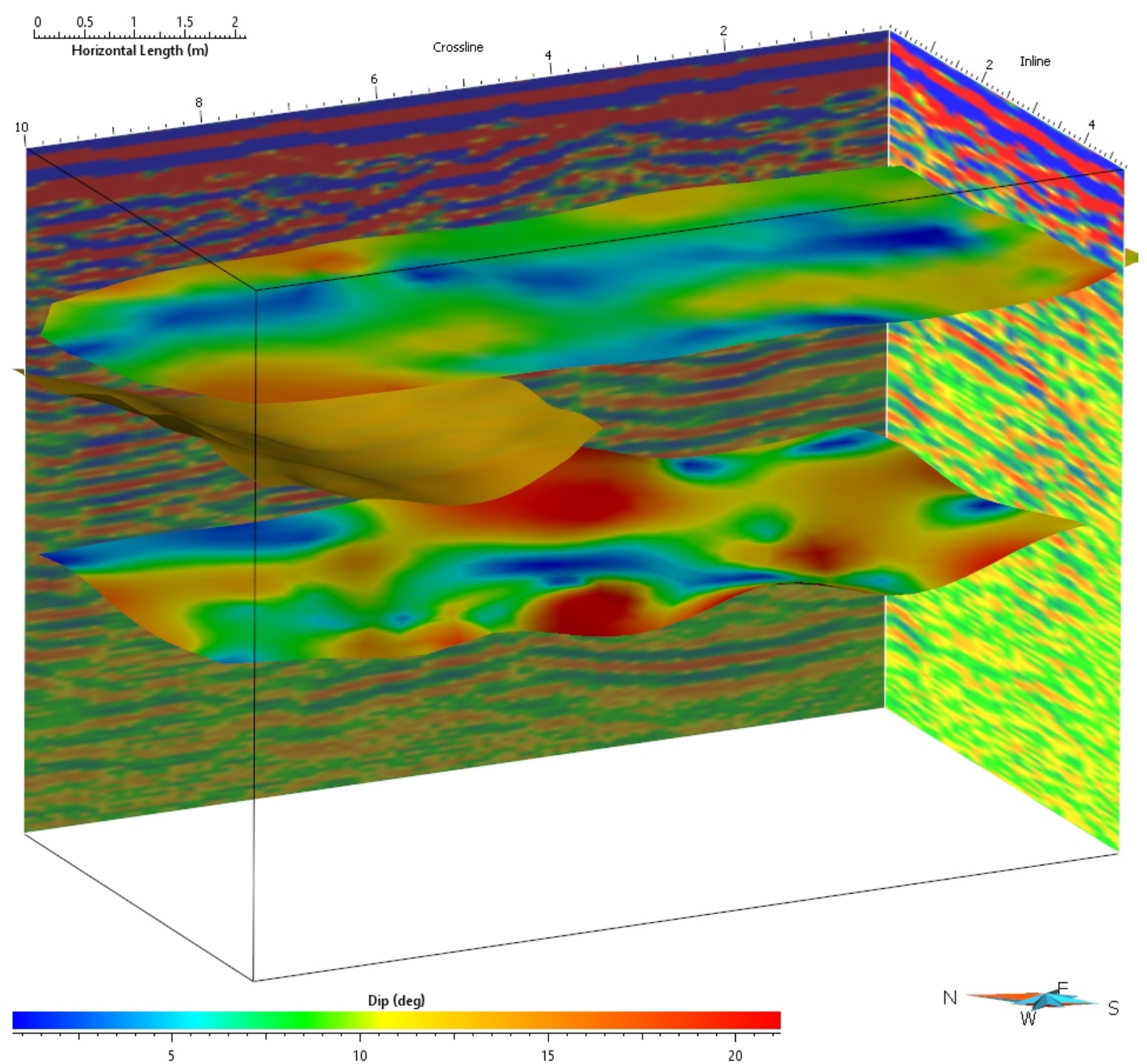

Fig. 5. GPR dataset B (located on the upper bench) with horizon inclination (dip in degrees) displayed on some of the horizons

The second horizon (trough-shaped) associated with facies Z4/Z5 does not show dip for clarity of the image; total vertical reach in TWTT is $220 \mathrm{~ns}(100 \mathrm{~ns}=4.35 \mathrm{~m})$

\section{SEDIMENTARY INTERPRETATION OF RADAR FACIES}

Linking the radar facies in GPR datasets with the lithofacies described in the quarry exposures and therefore also the processes that shaped them was possible using the main attributes describing radar facies: shape of reflection surfaces (including their continuity), their amplitude, dip and azimuth of inclination. As identified by Blair and McPherson (1994b), bedding inclination within alluvial fan deposits can suggest the depositional processes responsible for their formation. Thus, a parallel steeply inclined (8 to $20^{\circ}$ ) tabular arrangement of radar reflections, occasionally with deeply incised scour-shaped reflections, as in the case of dataset $D$, can certainly be interpreted as lithofacies Z1 or Z2 described by Zbroja et al. (1998). These sediments were deposited by cohesive and noncohesive debris flows, represented respectively by matrix- and framework-supported gravels. They could not be distinguished between each other based only on the pattern of GPR reflections, while exposure correlation was not always available. A statistical summary done with the geomodelling software showed that facies $Z 1$ and $Z 2$ together represent about $50 \%$ of lithofacies in all GPR datasets, which supports observations in quarry exposures made by Zbroja et al. (1998).

The subhorizontal parallel stratification suggested lithofacies Z3 was deposited by laminar catastrophic flood flows. The inclination of this stratification was $<8^{\circ}$. Although channels can sometimes also be present within debris flow deposits, channels in alluvial fans are most often associated with confined flash flood deposits (Blair and McPherson, 1994a). Thus trough-shaped concordant reflections were used to identify lithofacies Z4 or Z5. Lithofacies Z4 was deposited by waning tractional currents as described by Nemec and Steel (1984) or perhaps are debris flow or flash flood deposits reworked during periods of fair weather (Z4). Although reflections resembling cross-stratification were noticed within channels on some of the profiles, they could not be clearly distinguished from lithofacies $Z 5$, i.e. channelized flashflood deposits. Therefore radar facies $\mathrm{Z} 4$ and Z5 have been merged. Radar facies correlated with the lithofacies of Zbroja et al. (1998) are summarized in Figure 6. 


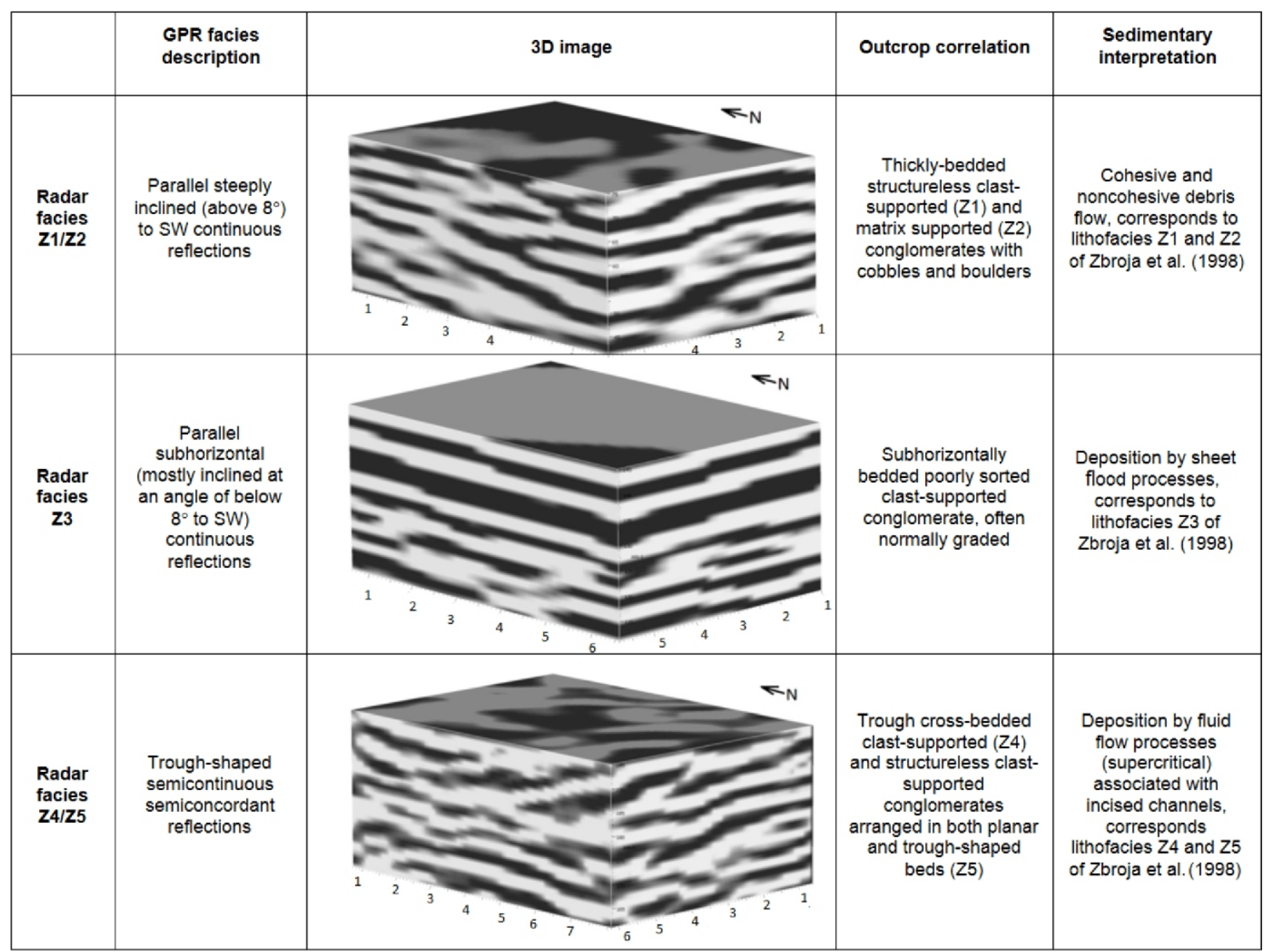

Fig. 6. Classification of radar facies together with correlation with lithofacies and sedimentary interpretation, units in the 3D representations expressed in metres

\section{MULTIPLE POINT STATISTICS (MPS)}

MPS simulations were carried out using the Improved Parallel Multiple Point Algorithm (IMPALA, Straubhaar et al., 2010) by Ephesia incorporated in SKUA-GOCAD software. In contrast to two-point geostatistics (for example krigining), which is based on semivariogram and relationships for pairs of measurement points, multiple point statistics takes into account spatial relationships between multiple measurement points (Guardiano and Srivastava, 1992). These relationships between data points can be obtained from training images (Strebelle, 2000, 2002) in order to reproduce similar geometrical patterns of value distribution. MPSs have been applied to predict the distribution of properties in inaccessible geological situations, for example the distribution of hydraulic conductivity within hydrocarbon reservoir rocks or aquifers (Ronayne et al., 2008; Comunian et al., 2011; Linde et al., 2015).

The 3D radar facies were painted on each of pseudo-3D GPR datasets (see dataset $C$ in Figs. 7 and 8) in SKUA-GOCAD. Field observations of the position of lithofacies Z5 (uppermost quarry face) and Z1 (lowermost cliff), together with radar facies from GPR datasets, were transferred to a single geological grid with lateral dimensions of $120 \times 80 \mathrm{~m}$ and a height of $35 \mathrm{~m}$. The grid was built of cells, each with dimensions of $1.2 \times 1.2 \times 0.45 \mathrm{~m}$. This grid was used to simulate the distribution of lithofacies at the quarry scale. Thirty realizations from
MPS simulations were created using all available information on the lithofacies distribution from five GPR datasets and field observations. GPR dataset C (Fig. 8) was used as a training image because its facies proportions were the most similar to the proportion of facies established using all GPR datasets.

The realizations from MPS simulations were used to compute probabilities using SKUA-GOCAD to find the most likely solution. Quantile values between 0 and 1 represent contiguous ranges of equal probability. In the case of 10-quantile, 0.5 quantile is the same as the median on a cumulative probability curve, i.e. the middle value on a cumulative probability curve. This result is used as the most probable (Fig. 9A). In order to graphically demonstrate uncertainty associated with this estimation, realisations for quantiles between 0.2 and 0.8 are shown in Figure 9B-E.

\section{DISCUSSION}

The radar facies were classified and interpreted as sedimentary facies mostly based on shape of reflections and their dip of inclination. These features cannot be inferred from 2D data (2D GPR profiles or rock exposures), particularly in such complex depositional systems as alluvial fans. The study demonstrated how 3D geophysical methods supported by stochas- 


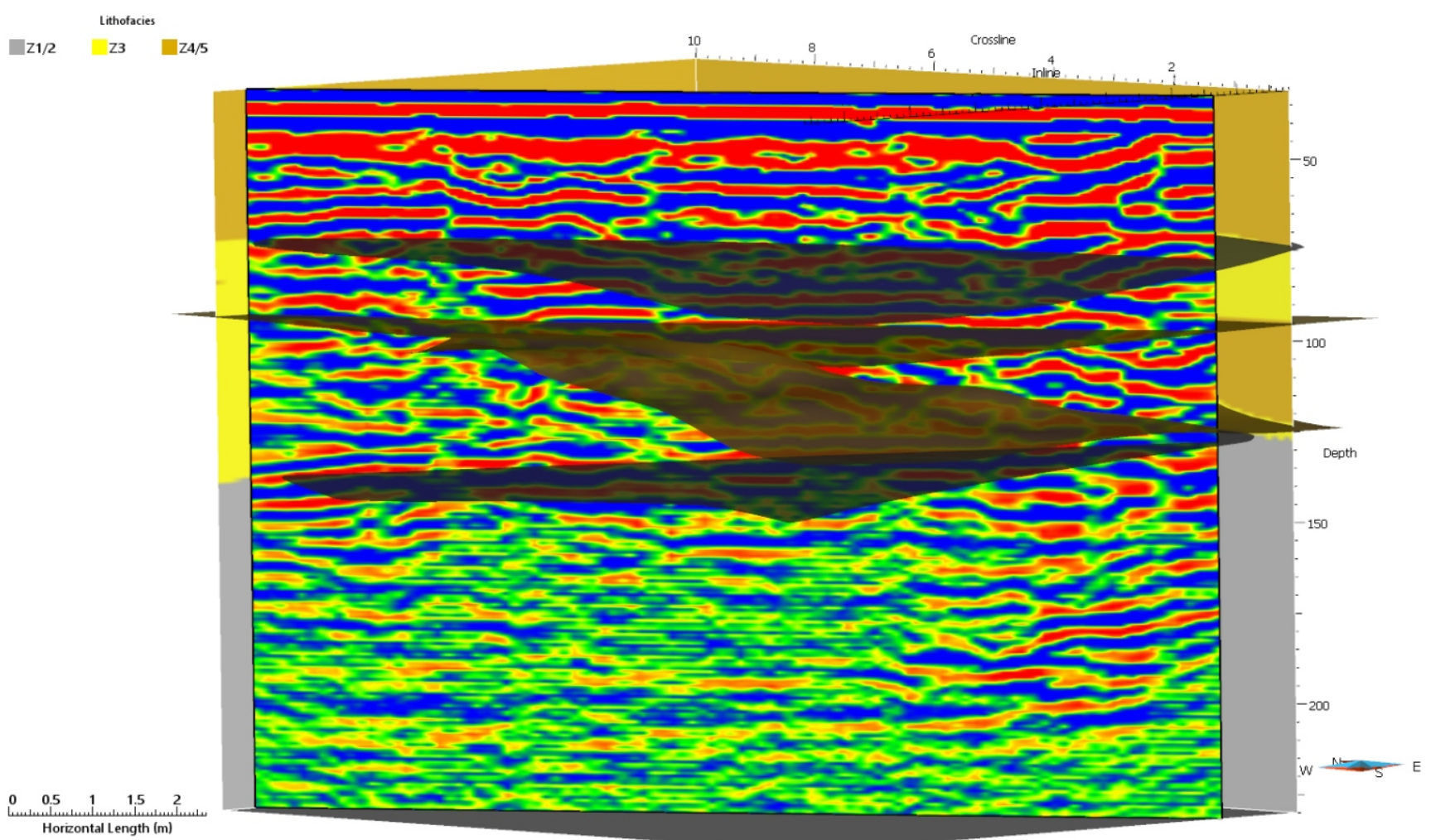

Fig. 7. 2D oblique section through dataset $\mathrm{C}$ orthogonally to the dip direction of the uppermost surface

Only bounding surfaces are displayed for the clarity of the image; compare with Figure 8; lateral dimensions in $\mathrm{m}$, vertical scale in showing TWTT in ns (100 ns $=4.35 \mathrm{~m})$

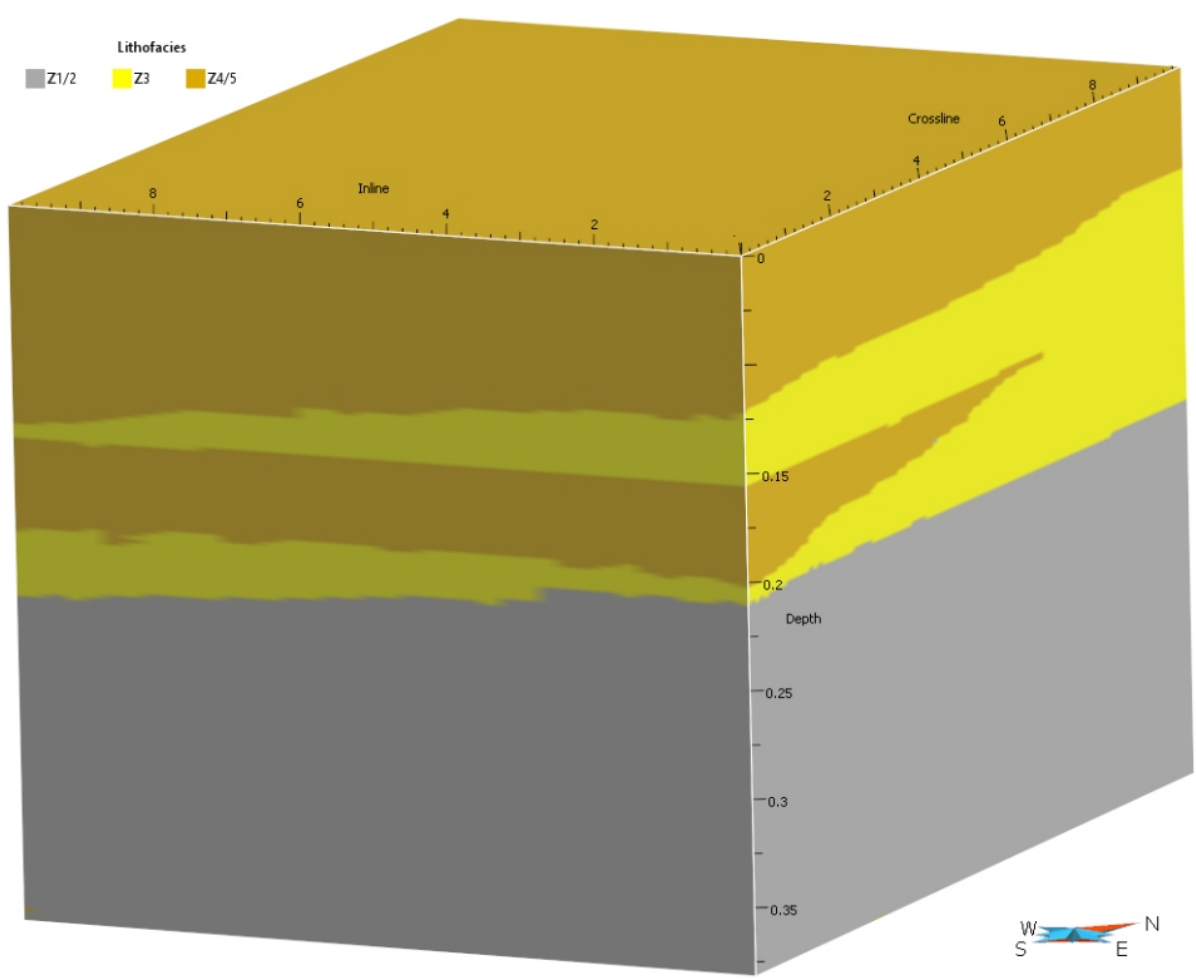

Fig. 8. GPR dataset $C$ located in the western part of the second-from-the-bottom level of the quarry with lithofacies Z1/2 (grey), Z3 (yellow) and Z4/5 (orange)

Lateral dimensions in metres, vertical scale in showing TWTT in hundreds of ns (100 ns $=4.35 \mathrm{~m})$ 

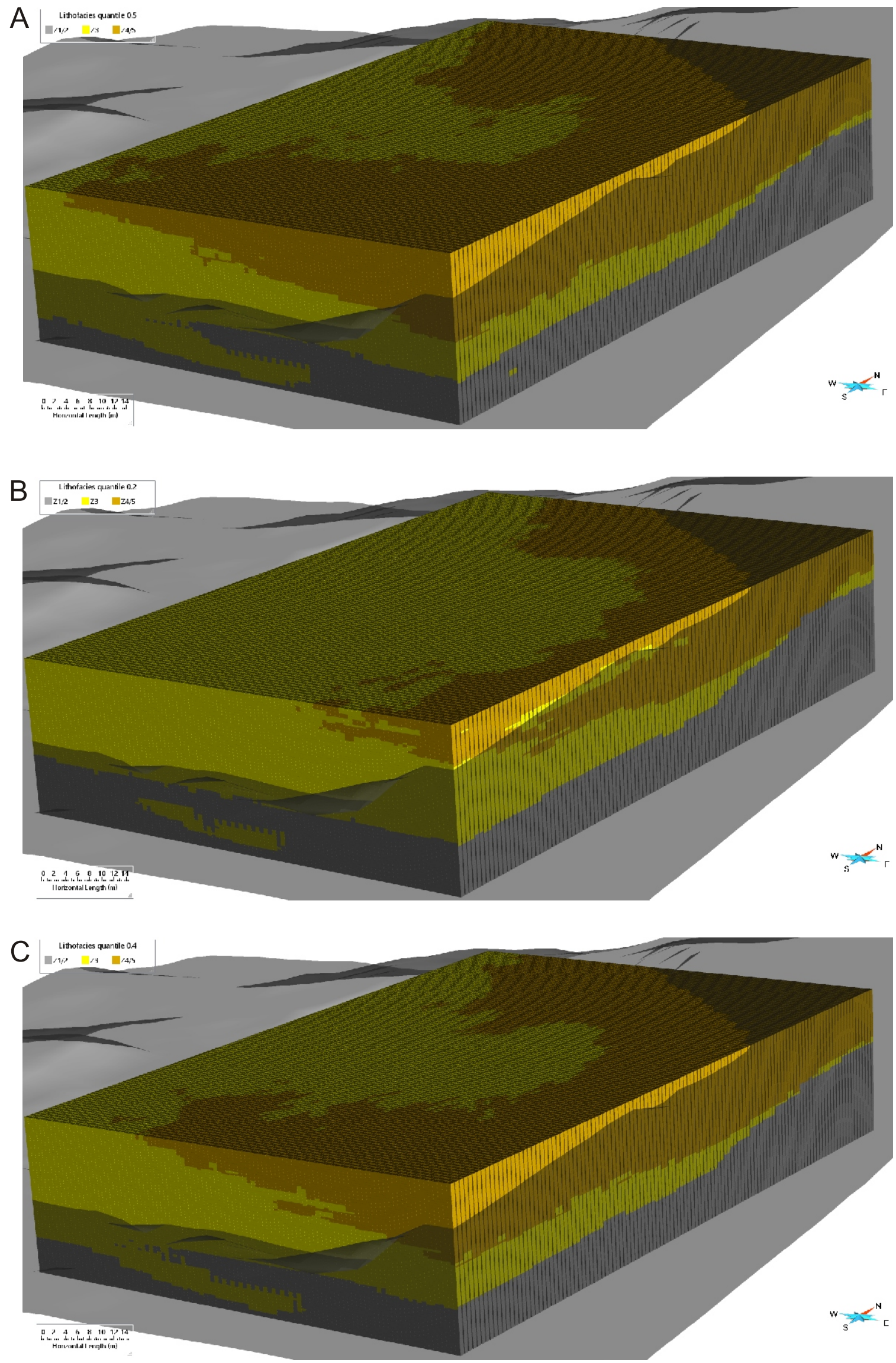

Fig. 9. Result of MPS estimation for quantile

A -0.5 based on 30 simulations of facies distribution in the quarry-wide geological grid with lateral dimensions of $120 \times 80 \mathrm{~m}$ and a height of $35 \mathrm{~m}$; B - 0.2; C -0.4 to demonstrate uncertainty associated with MPS simulations based on pseudo-3D GPR data; radar facies: Z1/2 (grey), Z3 (yellow) and Z4/5 (orange); grey surface represents the ground surface around the Zygmuntówka Quarry 

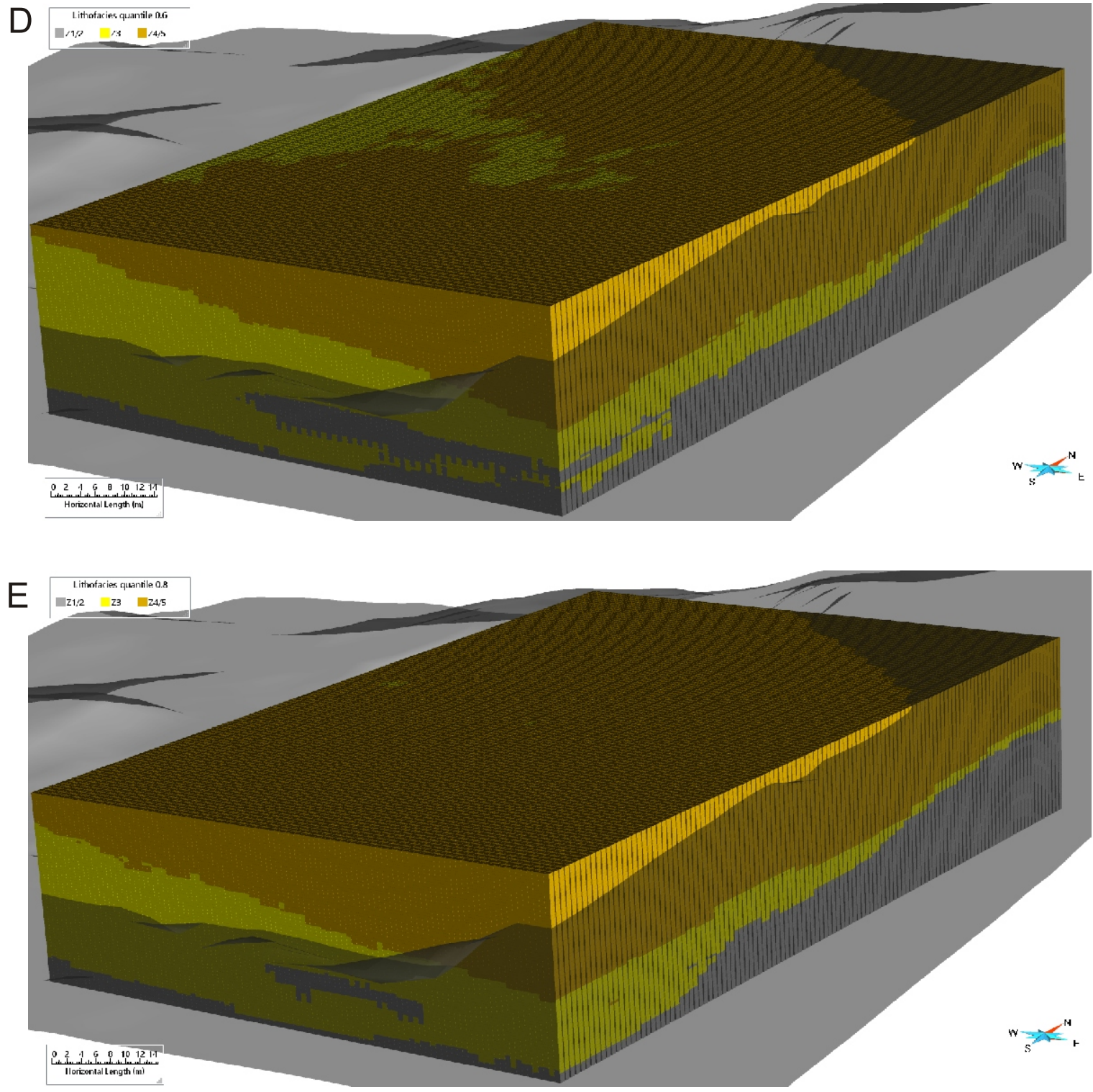

Fig. 9. Result of MPS estimation for quantile

D - 0.6; E - 0.8 to demonstrate uncertainty associated with MPS simulations based on pseudo-3D GPR data; radar facies: Z1/2 (grey), Z3 (yellow) and Z4/5 (orange); grey surface represents the ground surface around the Zygmuntówka Quarry

tic modelling can be used to reconstruct sedimentary facies distribution at a local scale in order to construct reliable training images for further MPS simulations of facies distribution in new geological situations.

The sedimentary facies of fanglomerates identified with GPR comprise cohesive and non-cohesive gravity flow deposits (Z1 and Z2) as well as fluid gravity flow deposits, both unconfined sheetflood (Z3) and confined channel fills (Z5). Zbroja et al. (1998) also identified lithofacies Z4 either related to waning traction currents or reworking of debris flow or flash flood deposits during periods of normal weather. According to Zbroja et al. (1998), this lithofacies was limited to two beds of lateral extent of $4 \mathrm{~m}$ and total thickness reaching $3.2 \mathrm{~m}$. Because the last two facies are both associated with trough-shaped surfaces, they cannot be differentiated from lithofacies $Z 5$ on radar images. Thus, modelling of the distribution of stream flow deposits (lithofacies Z4) had to be abandoned and lithofacies Z5 was given a greater importance.
The sedimentary architecture suggests that the study site preserves a transitional section of alluvial fan between what Blair and McPherson (1994a) described as a type I alluvial fan (in the lower section of the quarry profile) and type II (above). Type I alluvial fans are dominated by debris flows, mass-wasting processes and possible incised channels and gullies in their upper part, typically with average slope inclination between 5 and 15 , while type II is dominated by unconfined and confined flash floods with slope inclination of between 2 and 8 .

The training image constructed from this study site using all data available - the most probable facies distribution at entire quarry scale, as illustrated in Figure $9 \mathrm{~A}$ - shows the arrangement of all major facies. This training image should be suitable to carry out simulations of sedimentary facies distribution in most palaeogeographical settings and stages of fan development. The Devonian subcrop surface was digitally delineated based on the Geological Map of Poland at the scale of 1:50,000 (Hakenberg, 1971). This allows referring of the training image to 
the local paleaogeography and therefore its use in MPS simulations in different palaeotectonic situations.

In the Gorzów Block, the sedimentary material building alluvial fan deposits mostly includes fragments of Lower Permian volcanic rocks, although in some areas (borehole Banie 1) only material derived from Carboniferous sedimentary rocks was found within the conglomerates. As explained in the introduction, during the phase of facies reconstruction (MPS simulations) differences in the lithological composition of sedimentary material can be addressed by setting facies proportions based on hard data from boreholes. The phase of application of the training image will discussed in a separate publication.

\section{CONCLUSIONS}

The study highlighted application of pseudo-3D GPR data to create a training image for MPS simulations. The alluvial fan architecture, dominated by deposits of both debris flows and flash floods, was investigated using pseudo-3D GPR data collected from the quarry exposures. It was statistically analysed and lithofacies distribution across the quarry was reconstructed in order to create a training image, i.e. the most probable (quantile 0.5 ) digital model of facies distribution. This model can be used in analogous situations, and will be tested on alluvial fan facies in the Permian system of the Gorzów Block.

Acknowledgements. The study was carried out as part of PGI-NRI project: 3D Geological Model of Sedimentary Cover of the Gorzów Block, project No. 22.2609.1501.00.1. The authors would like to thank the editor A. Wysocka as well as R.L. Van Dam and an anonymous reviewer whose contribution significantly improved the manuscript. We also would like to acknowledge fruitful discussions with $\mathrm{H}$. Kiersnowski from PGI-NRI. Paradigm is thanked for making SKUA-GOCAD available for this project.

\section{REFERENCES}

Beres, M., Haeni, F.P., 1991. Application of ground-penetrating-radar methods in hydrogeologic studies. Ground Water, 29: 375-386.

Blair, T.C., 2000. Sedimentology and progressive tectonic unconformities of the sheetflood-dominated Hell's Gate alluvial fan, Death Valley, California. Sedimentary Geology, 132: 233-262.

Blair, T.C., McPherson, J.G., 1992. The Trollheim alluvial fan and facies model revisited. GSA Bulletin, 104: 762-769.

Blair, T.C., McPherson, J.G., 1994a. Alluvial fan processes and forms. In: Geomorphology of Desert Environments (eds. A.D. Abrahams and A.J. Parsons): 14-402. Chapman and Hall, London.

Blair, T.C., McPherson, J.G., 1994b. Alluvial fans and their natural distinction from rivers based on morphology, hydraulic processes, sedimentary processes, and facies assemblages. Journal of Sedimentary Research, 64: 450-489.

Comunian, A., Renard, P., Straubhaar, J., Bayer, P., 2011 Three-dimensional high resolution fluvio-glacial aquifer analog - Part 2: Geostatistical modeling. Journal of Hydrology, 405 . 10-23.

Dogan, M., Van Dam, R.L., Bohling, G.C., Butler, J.J., Hyndman, D.W., 2011. Hydrostratigraphic analysis of the MADE site: integration of full resolution GPR and hydraulic conductivity data. Geophysical Research Letters, 38: L06405.

Gani, M.R., 2004. From turbid to lucid: A straightforward approach to sediment gravity flows and their deposits. The Sedimentary Record, 2: 4-8.

Gawthorpe, R.L., Collier R.E.L., Alexander, J., Leeder, M., Bridge, J.S., 1993. Ground penetrating radar, application to sand body geometry and heterogeneity studies. Geological Society of London Special Publication, 73: 421-432.

Grasmueck, M., Weger, R., Horstmeyer, H., 2005. Full-resolution 3D GPR imaging. Geophysics, 70: K12-K19.

Guardiano, F.B., Srivastava, R.M., 1992. Multivariate geostatistics: beyond bivariate moments. Quantitative Geology and Geostatistics, 5: 133-144

Hakenberg, M., 1971. Szczegółowa mapa geologiczna Polski w skali 1:50 000, arkusz 850, Chęciny (in Polish). Instytut Geologiczny, Warszawa.

Huggenberger, P., 1993. Radar facies: recognition of facies patterns and heterogeneities within Pleistocene Rhine gravels, NE Switzerland. Geological Society Special Publications, 75: 163-176.
Karnkowski, P.H., 1994. Rotliegend lithostratigraphy in the central part of the Polish Permian Basin. Geological Quarterly, 38 (1): $27-42$

Kiersnowski, H., Buniak, A., 2006. Evolution of the Rotliegend Basin of northwestern Poland. Geological Quarterly, 50 (1): 119-138.

Kim, B.C., Lowe, D.R., 2004. Depositional processes of the gravelly debris flow deposits, South Dolomite alluvial fan, Owens Valley, California. Geosciences Journal, 8: 153-170.

Kostecka, A., 1962. Characteristic of Zechstein conglomerates of Gałęzice-Bolechowice Syncline (Holy Cross Mountains) (in Polish with English summary). Kwartalnik Geologiczny, 6 (3): 416-435.

Kuleta, M., Zbroja, S., Nawrocki, J., 2007. Permian conglomerates of Zygmuntówka quarry. In: Fieldtrip guide for International Workshop on the Triassic of Southern Poland, Fourth Meeting for Pan-European Correlation of the Epicontinental Triassic (eds. J. Szulc and A. Becker): 64-67. Państwowy Instytut Geologiczny, Warszawa.

Linde, N., Lochbühler, T., Dogan, M., Van Dam, R.L., 2015. Tomogram-based comparison of geostatistical models: application to the macrodispersion experiment (MADE) site. Journal of Hydrology, 531: 543-556.

Maejima, W., Nakanishi, T., 1994. Middle Miocene alluvial fan-fan delta sedimentation: the Kanaso conglomerate and sandstone member of the Togane formation to the North of Hamada, Southwest Japan. Journal of Geosciences, Osaka City University, $\mathbf{3 7}$ 55-75.

Middleton, G.V., Hampton, M.A., 1973. Sediment gravity flows: mechanics of flow and deposition. In: Turbidites and Deep-water Sedimentation (eds. G.V. Middleton and A.H. Bouma): 1-38. Pacific Section SEPM, Los Angeles.

Migaszewski, Z., Hałas, S., Durakiewicz, T., 1996. The age and origin of the calcite mineralization in the Holy Cross Mts based on lithologic-petrographic and isotopic evidence (Central Poland) (in Polish with English summary). Przegląd Geologiczny, 43: 275-281.

Mitchum, R.M., Vail, P.R., Sangree, J.R., 1977. Seismic stratigraphy and global changes of sea level, Part 6: Stratigraphic Interpretation of Seismic Reflection Pattern. AAPG Memoir, 26: 117-133.

Nemec, W., 2009. What is a hyperconcentrated flow? In: Abstract book, 27th Annual Meeting of the International Association of 
Sedimentologists (eds. V. Pascucci and S. Andreucci), Alghero, September 20-23, 2009.

Nemec, W., Postma, G., 1993. Quaternary alluvial fans in southwestern Crete: sedimentation processes and geomorphic evolution. IAS Special Publication, 17: 235-276.

Nemec, W., Steel, R.J., 1984. Alluvial and coastal conglomerates: Their significant features and some comments on gravelly mass flow deposits. Canadian Society of Petroleum Geologists Memoir, 10: 1-31.

Pokorski, J., 1988. Rotliegendes stratigraphy in the north-western Poland. Bulletin of Polish Academy of Sciences, Earth Sciences, 36: 99-108.

Ronayne, M.J., Gorelick, S.M., Caers, J. 2008. Identifying discrete geologic structures that produce anomalous hydraulic response: an inverse modeling approach. Water Resources Research, 44: W08426.

Simons, E.V., Richardson, D.B., 1966. Resistance to flow in alluvial channels. US Geological Survey Professional Paper, 422: $1-61$.
Straubhaar, J., Renard, P., Mariethoz, G., Froidevaux, R., Besson, O., 2010. An improved parallel multiple-point algorithm using a list approach. Mathematical Geosciences, 43: 305-328.

Strebelle, S., 2000. Sequential simulation drawing structures from training images. Unpublished Ph.D. thesis, Stanford University.

Strebelle, S., 2002. Conditional simulation of complex geological structures using multiple-point statistics. Mathematical Geology 34: 1-21.

Taylor, G., Eggleton, R.A., 2001. Regolith geology and geomorphology. John Wiley and Sons Chichester, UK.

Thiry, M., Schmitt, J.M., Simon-Coinçon, R., 1999. Problems, progress and future research concerning palaeoweathering and palaeosurfaces. Special Publications of International Association of Sedimentologists, 27: 3-17.

Zbroja, S., Kuleta, M., Migaszewski, Z.M., 1998. New data on conglomerates of quarry "Zygmuntówka" in the Holy Cross Mts (in Polish with English summary). Biuletyn Państwowego Instytutu Geologicznego, 379: 43-59. 